\title{
The Price of Dissent: The Iowa Farmers Union and the Early Cold War, 1945-1954
}

\section{BRUCE FIELD}

SINCE THE FALL OF THE BERLIN WALL and the disintegration of the Soviet Union, Americans have applauded the supposed U.S. victory in the Cold War. The public has neglected the Cold War's damaging impact on U.S. society, however. For example, citizens pay scant attention to the injustices of McCarthyism, a movement that historian Stanley Kutler dramatically

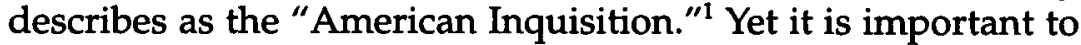

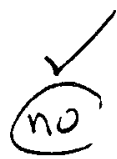
remember nation-shaping events such as the purge of the China experts, the trial of Alger Hiss, and the exaggerations of the House Committee on Un-American Activities. While it did not receive the exposure of these better-known events, the fate that befell the Iowa Farmers Union and its president, Fred Stover, between 1945 and 1954 illustrates the Cold War's effects on Iowa's history.

The Iowa Farmers Union was one of fifteen affiliates of the National Farmers Union (NFU), the nation's third-largest general farm organization. ${ }^{2}$ After World War II, the five hundred

1. Stanley I. Kutler, The American Inquisition: Justice and Injustice in the Cold War (New York, 1982).

2. After World War II, the American Farm Bureau Federation claimed the largest national membership (1.5 million members), while the National Grange served the interests of 800,000 farmers nationwide. The history of the Grange and the Farm Bureau can be found in a variety of sources. See Lowell Dyson, Farmers' Organizations (New York, 1986); Wesley McCune, Who's Behind Our Farm Policy (New York, 1956); and Walter W. Wilcox, Social Responsibility in

THE ANNALS OF IOWA 55 (Winter 1996). CThe State Historical Society of Iowa, 1996. 
thousand members of the NFU distinguished themselves from other organized farmers by publicly criticizing President Truman's foreign policy. Unlike members of the National Grange and the American Farm Bureau Federation, those in the National Farmers Union rejected a single-minded focus on overseas markets; likewise, they rejected the notion that Communism was the major roadblock to American success. Led by national president James G. Patton, the organization instead hoped that the United States would take a "cooperative role in shaping the future of the entire world." Speaking to the annual convention of the South Dakota Farmers Union in the fall of 1945, Patton argued that Americans needed to "learn to live in a peace based on patience, tolerance, and understanding of the peoples who do not speak our language, who do not use our form of government, and whose concepts are predicated upon centuries of economic, social, and political backgrounds widely different from ours. Specifically," he continued, "we must learn to live in this world with the great country of Russia. We simply must come to understand how Russian people think, why they do what they do, and then guide our foreign policy in terms of a firm position but with determination to cooperate to live in peace. ${ }^{13}$

Farm Leadership: An Analysis of Farm Problems and Farm Leadership in Action (Westport, CT, 1975).

3. James G. Patton, "The Federal Government's Role in the Postwar Economy," American Political Science Review 38 (1944), 1126; National Union Farmer, 15 October 1945. No overall assessment of the National Grange's or American Farm Bureau Federation's attitudes toward U.S. foreign policy has yet been attempted, but those organizations' procontainment views are evident in a number of readily available sources, including congressional hearings. See, for example, U.S. Congress, Senate, Committee on Foreign Relations, European Recovery Program: Hearings Before the Committee on Foreign Relations, 80th Cong., $2 \mathrm{~d}$ sess. (1948); U.S. Congress, House, Committee on Foreign Affairs, United States Foreign Policy for a Post-War Recovery Program: Hearings Before the Committee on Foreign Affairs, 80th Cong., 2d sess. (1948); U.S. Congress, Senate, Committee on Foreign Relations, North Atlantic Treaty: Hearings Before the Committee on Foreign Relations, 81st Cong., 1st sess. (1949); and U.S. Congress, Senate, Committee on Foreign Relations, Mutual Security Act of 1952: Hearings Before the Committee on Foreign Relations, 82d Cong., 2d sess. (1952). One can also establish the procontainment views of the National Grange and American Farm Bureau Federation by examining State Department studies. See, for example, Department of State, Office of Public Opinion Studies, Current 
The NFU, disappointed with U.S. policymakers' aggressive stance, denounced the major tenets of the Truman administration's policy of containment. It rejected continued development of atomic weapons in favor of "complete disarmament, right down to pistols." It judged Truman's $\$ 18$ billion military budget to be part of an unnecessary plan to "whale the tar out of somebody pretty soon." In keeping with his view of the Truman Doctrine as an example of "saber-rattling, oppressive imperialism," \im Patton warned against the Marshall Plan. He noted that the United-States could not "afford to take the position that we are a big bad Santa Claus who is footing the bills and therefore is going to be boss. ${ }^{\prime 4}$

The National Farmers Union's argument was as simple as it was direct. The United States, it argued, had failed to live up to its pronouncements of international cooperation. Instead, the United States had bypassed the newly created United Nations to shape the world as it saw fit. The Truman administration's approach rejected the cooperative spirit exhibited by the Allies during World War II. Preoccupied with strategic and defense concerns, it betrayed traditional American respect for national self-determination by supporting undemocratic regimes. It also contrived one crisis after another to justify American action in the place of what it claimed to be an inadequately prepared United Nations. The United States risked losing credibility with or alienating many of the world's peoples if they followed the Truman administration's scheme, according to the NFU. Further,

Attitudes of Farmer Organizations Toward International Relations, RG 59, National Archives; Department of State, Office of Public Opinion Studies, Attitudes of Farmer Organizations Toward International Issues, 1951-1952, RG 59, National Archives; and Department of State, Office of Public Opinion Studies, Opinions and Activities of American Private Organizations and Groups, RG 59, National Archives. Finally, one can deduce National Grange and American Farm Bureau Federation viewpoints by examining their organizational newspapers, The Grange News and American Farm Bureau Federation Official Newsletter.

4. "Statement of James G. Patton Before the Executive Committee of the National Board of Directors, National Farmers Union, December 17, 1946," p. 3, box 2, Farmers Union of the New York Milk Shed Records, 1939-1957, Cornell University Library; Iowa Union Farmer, 28 September 1946; National Union Farmer, 1 April 1947; James G. Patton to Earl O. Shreve, 18 November 1947, box 1453, RG16, Secretary of Agriculture, General Correspondence 1906-1975, National Archives. 
its aggressive stance interfered with the re-establishment of economic ties between western and eastern Europe. Finally, it squandered American dollars on containment of a supposed Communist threat. This money might be better spent, the NFU insisted, on domestic development, such as programs to assist the nation's embattled family farmers. ${ }^{5}$

Between 1945 and 1949, the National Farmers Union opposed U.S. foreign policy persistently and intensely. Maintaining its principled opposition to the Truman administration grew more difficult, however, in the summer of 1950. On June 25, 1950, North Korean troops crossed the 38th Parallel. The. United States and United Nations interpreted the action as Communist aggression and sent troops to assist South Korea. Shortly after the deployment of U.S. troops, Jim Patton assured President Truman that the NFU supported his efforts in Korea. After conferring with his executive committee, Patton issued an eightparagraph position statement on "the Present Crisis in Asia." He reminded members that the organization had "openly criticized" U.S. foreign policy in the past, but concluded that the "evil" actions of the Soviet Union in "fomenting armed aggression" in Korea had made United States and United Nations action necessary. Patton's appeal to his executive committee made it clear why he favored such a policy reversal. "I believe," he wrote, "that the primary function of the Farmers Union and its officials is to preserve that Union. And I am sure that if our Union is to be preserved and looked upon and heard as a responsible organization in the United States, it is absolutely necessary for us to support the United Nations and to support our Government which is now at war."

5. The National Farmers Union also disagreed with the National Grange and the American Farm Bureau Federation over other issues besides foreign policy, most notably in its advocacy of an active governmental role in the economic life of the nation. As the self-professed spokesgroup for the nation's "family farmers," the NFU advocated direct government support programs and questioned the other two groups' emphasis on pure free enterprise capitalism.

6. Undated interoffice communication of the National Farmers Union, summarizing the 18 July 1950 meeting between Jim Patton and President Truman, box 10, James G. Patton Papers, Western Historical Collections, University of Colorado Library; Policy Statement of James G. Patton, President, National Farmers Union, 8 September 1950, series no. 5, box 4, National Farmers Union 
In the months that followed, Patton reiterated his new-found support for U.S. foreign policy. Although he had vigorously protested an annual defense budget of $\$ 18$ billion in 1946, by late 1950 he had changed his mind. "My own personal opinion," he wrote in a letter to Air Force Secretary Stuart Symington, "is that we should spend $\$ 50$ billion a year for the next three years on the defense effort just on the basis that we are going to present a stronger armed position. If we must get ready for a major war with Russia, then I think we should do our planning on the basis of spending half of our national income for that effort."

In October 1950 Patton told the South Dakota Farmers Union that U.S. policymakers needed to realize "that aggression anywhere in this closely knit world is an eventual threat to our security at home." By January 1951, Patton seemingly exceeded the zeal of Truman administration policymakers, suggesting that modified containment was inadequate and arguing for more forceful steps. ${ }^{8}$

Several factors contributed to Patton's clear reversal of policy, including the volatile state of postwar liberalism reflected in Henry Wallace's disappointing presidential campaign in 1948. ${ }^{9}$ More than anything, however, Patton desired to "preserve the [National Farmers] Union ... as a responsible organization in the United States." To accomplish that goal, Patton had to counter damaging charges of sympathy with, and even direct

Papers (hereafter cited as NFU Papers), Western Historical Collections, University of Colorado Library; Minutes of the Executive Committee of the National Farmers Union, 25 July 1950, and Report of James G. Patton, President, National Farmers Union, to the Executive Committee, 24-26 July 1950, Fred Stover Papers, Special Collections Department, University of Iowa Libraries. (The Stover Papers are as yet unprocessed, and so more exact citations in this and subsequent footnotes are not possible.).

7. Iowa Union Farmer, 28 September 1946; Patton to Symington, 21 September 1950, box 7, folder 9, Patton Papers.

8. James G. Patton, "Address to South Dakota Farmers Union Convention," 5 October 1950, box 24, folder 6, Patton Papers; Patton to Symington, 22 January 1951, box 7, folder 26, Patton Papers.

9. See William C. Pratt, "The Farmers Union and the 1948 Henry Wallace Campaign," Annals of Iowa 49 (1988), 349-70; see also idem, "Glenn J. Talbott, the Farmers Union, and American Liberalism after World War II," North Dakota History 55 (1988), 3-13. 
control by, Communist agents. ${ }^{10}$ Although the supporting evidence consisted mostly of fabrication, Americans generally believed that the National Farmers Union was at least sympathetic to Soviet aims, if not directly controlled by Moscow.

Some of the most vocal critics of the NFU were members of the National Farmers Union themselves. ${ }^{11}$ In 1946, for example, Nebraska Farmers Union president Chris Milius accused the national organization of being "Communistic." Gardner Jackson, who had served the National Farmers Union in a variety of unofficial capacities since 1936, also accused the organization and its leadership of being "bewitched by the siren song of salvation for humanity sung by the Communists." In 1947, National Union Farmer editor James Elmore resigned over the issue, accusing Patton and the Union's "confused left-wing leadership" of "playing footie" with the Communists and of following a "pro-communist collaborationist line."12

10. Studies of the role of the Communist Party in American agriculture have cautioned scholars not to overestimate the strength of the relationship between farmers and Communist sympathizers. It is true, however, that the NFU's outspoken criticism of U.S. policy convinced many contemporaries that the group had succumbed to the internal borings of Communist moles. See Lowell Dyson, Red Harvest: The Communist Party and American Farmers (Lincoln, NE, 1982); William C. Pratt, "Farmers, Communists, and the FBI in the Upper Midwest," Agricultural History 62 (1989), 61-80.

11. The National Farmers Union had a lengthy history of internal squabbling that dated to the founding of the organization in Texas in 1902. Early bickering over the predominance of Texans in leadership roles was followed in subsequent years by intense disputes over whether to expand political activity, whether to allow nonfarmers to become members, and whether to support the policies of the New Deal. The occasional intensity of these internal debates led Jim Patton to characterize one four-year period in the organization's history as an "Irish Picnic" in which "everybody grabbed a shillala and hit the first person he could see." Quoted in Charles H. Livermore, "James G. Patton: Nineteenth-Century Populist, Twentieth-Century Organizer, TwentyFirst-Century Visionary" (Ph.D. diss., University of Denver, 1976), 15. The history of the National Farmers Union is treated at length in John A. Crampton, The National Farmers Union: Ideology of a Pressure Group (Lincoln, NE, 1965); and William P. Tucker, "Populism Up-to-Date: The Story of the Farmers Union;" Agricultural History 21 (1947), 198-208.

12. Patton to Members of Farmers Educational and Cooperative Union of America, Nebraska Division, 15 November 1946, Stover Papers; Jackson to Patton, 3 August 1946, box 57, Gardner Jackson Papers, Franklin D. Roosevelt Library, Hyde Park, New York; Elmore to Patton, 9 September 1947, box 35, 
Patton responded to these charges by accusing Milius of having a "narrow creviced mind" and by describing Jackson's charges as "so preposterous as to warrant disregard." ${ }^{13}$ His anger stemmed both from the disloyalty of National Farmers Union colleagues and from the unsubstantiated nature of their charges. Patton found himself in a frustrating situation as the charges of Communist sympathizing grew: how could the Farmers Union, amidst the anti-Communist hysteria of the time, simultaneously remain an organization of dissent and a key player in the world of Washington politics?

In the 1930s and early 1940s, the National Farmers Union had criticized an unholy alliance between business and government, one that it believed contributed to the demise of the nation's family farmers. Although critical of government-business cooperation, the NFU had maintained a degree of respect and influence in Washington; Patton and other National Farmers Union officials frequently testified before congressional committees and served in a number of advisory positions. ${ }^{14}$ Criticism of the nation's economic system was one thing, but criticism of its foreign policy, particularly as Americans began dying in Korea, was quite another. As charges of subversion mounted in 1950, Jim Patton recognized that he and other organization officials needed to mute their criticism of American foreign policy or risk losing their influence in Washington. With this in mind, Patton decided to reverse the NFU's longstanding

Aubrey Williams Papers, Franklin D. Roosevelt Library; Elmore to Aubrey Williams, 9 September 1947, box 35, Williams Papers; J. A. Spengler to Mrs. Frank P. Leo, 28 March 1956, series no. 14, box 2, NFU Papers.

13. Patton to Members of Farmers Educational and Cooperative Union of America, Nebraska Division, 15 November 1946, Stover Papers; Patton to Jackson, 14 November 1946, box 57, Jackson Papers.

14. Biographical information on Jim Patton's early career can be found in Charles Livermore's dissertation and Crampton's Ideology of a Pressure Group, 115-20. See also Dyson, Red Harvest, 189-92; Alonzo Hamby, Beyond the New Deal: Harry S. Truman and American Liberalism (New York, 1973), 149-50; Dyson, Farmers' Organizations, 224-27; Carey Longmire, "Colorado Cyclone," unpublished paper, 13 March 1946, box 27, folder 17, Patton Papers; and Steven A. Chambers, "Relations Between Leaders of the Iowa and National Farmers Union Organizations, 1941 to 1950" (honors thesis, Iowa State University, 1961), 15-24. 
opposition to U.S. foreign policy by supporting American involvement in Korea. Most National Farmers Union officials moved along with Patton, either softening their criticisms of U.S. foreign policy or wholeheartedly supporting the war in Korea. A few, most notably Iowa Farmers Union president Fred Stover, refused to do so.

STOVER HAD MATCHED Jim Patton's fervor and had denounced the Truman administration's foreign policy since assuming the presidency of the Iowa Farmers Union in 1945. In an April 1947 editorial in the Iowa Union Farmer titled "Imperialism at its Worst," Stover assailed President Truman. He charged that Truman had betrayed Jeffersonian revolutionary ideology through his support of "tottering monarchies" and "forces of oppression" in Greece and Turkey. After the 1948 elections, Stover argued eloquently against the nation's "reactionary militaristic foreign policy," decrying the effort to have "both guns and butter." As 1949 dawned, Stover bitterly described the newly announced North Atlantic alliance as a "North Atlantic Deception" that "mortgage[d] our lives to war. ${ }^{15}$ Stover's condemnation of President Truman's policies and his involvement in a number of international peace organizations made him the most visible National Farmers Union official at the state level, with the possible exception of North Dakota president Glenn Talbott. In 1950 these activities also made him the subject of FBI and State Department investigations. Finally, his unwillingness to bridle his criticism of U.S. foreign policy made him a likely target for an NFU purge sponsored by Jim Patton. ${ }^{16}$

Jim Patton had acted on his uneasiness about the future of the National Farmers Union even prior to the Korean War. In late 1949 and early 1950 he had orchestrated the removal of Denver headquarters worker Lee Fryer, organization legal coun-

15. Iowa Union Farmer, 19 April 1947, 20 November 1948, 19 March 1947, 16 April 1949; National Union Farmer, January 1949.

16. FBI reports, 24 January 1956 and 18 August 1956, box 48, Iowa Farmers Union Records, Special Collections, Iowa State University Library; Canberra to State Department, 19 May 1950, 743.001/5-1950, box 3560, RG 59, National Archives. 
sel Cliff Durr, and Minnesota state president Einer Kuivinen. Stover believed that his highly publicized rejection of Truman's policies placed Iowa "next on the purge list." However, Stover remained naively optimistic that NFU members would prevent the organization from openly supporting the Truman administration. In a letter to Northeastern Division president Archie Wright, Stover concluded that Patton would probably try to curry political favors and "water down our foreign policy position by ambiguous language and doubletalk," but he "wouldn't dare" call for a total reversal of "our good position on foreign policy." 17

Stover's optimism ended when the Korean War began. Unlike Patton, who accepted the legality of Truman's actions, Stover charged President Truman with ordering troops into Korea prior to official United Nations action. ${ }^{18}$ In editorials and at Farmers Union meetings in Iowa and elsewhere, Stover challenged the government's explanation of events in Korea. Iowa Farmers Union members supported their leader's challenge and, at their annual conventions in 1950 and 1951, called for an end to the war. The State Department responded to Iowa Farmers Union charges, especially those in a December 1951 piece titled "Debunking the Lies About Korea," by issuing a lengthy restatement of United States' rationales for military involvement in Korea. ${ }^{19}$

Drawing the attention of the State Department was precisely what Jim Patton had hoped to avoid. So, as Stover and the Iowa Farmers Union persistently denounced American efforts in Korea, Patton decided to cut them loose from the

17. Fryer to Stover, 15 November 1949, Stover Papers; Minutes of the Alabama Farmers Union Board of Directors meeting at Montgomery, 12 April 1951, box 33, Williams Papers; Einer Kuivinen, "Peace is Paramount," undated leaflet published by The Committee for a Progressive State Legislature, Stover Papers; Stover to Wright, 21 December 1949 and 20 May 1950, Stover Papers.

18. Stover's sequencing of events mirrors the narrative of I. F. Stone's The Hidden History of the Korean War (New York, 1952).

19. "Convention Resolutions of the 34th Annual Convention of the Farmers Educational and Cooperative Union of America," Stover Papers; Iowa Union Farmer, October 1951, December 1951; John M. Patterson to Jim Youngdale, 28 February 1952, 795.00/1-1052, RG 59, National Archives. 
National Farmers Union. To do so, he used tactics, including contrivance and misrepresentations of fact, that mirrored those used by anti-Communist critics of the Farmers Union.

PATTON MADE HIS FIRST MOVE at the Iowa Farmers Union annual convention in Des Moines in September 1950. Although he was unable to attend the meeting, he sent an address that included a clear ultimatum. "The power to revoke ... state charters," Patton wrote, "is held by the National Farmers Union, to be exercised . . . in the case of intolerable departures from the democratically-adopted policies of a majority in convention." Patton also released a statement to the Des Moines Register, a newspaper that had opposed Stover for years and that had characterized the Iowa Farmers Union as "a tiny fringe of little consequence." In his statement to the newspaper, Patton announced that he was "totally in disagreement with Fred Stover's present position on international policy" and that he felt "certain that the members of the Iowa Farmers Union, too, almost to a man, disagree with him." ${ }^{20}$

Patton's message was clear. Stover was the problem, and the Iowa Farmers Union could retain its charter if the members removed Stover as president. Otherwise, it faced loss of affiliation with the national organization. Patton, however, was wrong about Iowa Farmers Union members. Not only was Stover reelected president, but the Iowa Farmers Union also called for "a settlement of the present war in Korea" that accorded with Stover's views. ${ }^{21}$

Having failed to unseat Stover by appealing to the state membership, Patton adopted a new strategy. With the help of a small dissident group of Iowa Farmers Union members, Patton tried to prove that Stover should be removed as president of the Iowa Farmers Union. He claimed that Stover had violated the national organization's constitutional mandate against non-

20. James G. Patton, "To the Délegates and Members of the Iowa Farmers Union in Convention at Des Moines, lowa," 19 September 1950, Stover Papers; Des Moines Register, 9 and 22 September 1950.

21. Convention Resolutions of the 34th Annual Convention of the Farmers Educational and Cooperative Union of America, Stover Papers. 
partisan activity when he served as cochairman of the Progressive Party. Patton directed the question to Washington, D.C. attorney Carl Berueffy, who returned the legal opinion that Stover should have resigned as Iowa Farmers Union president before accepting the position in the Progressive Party. According to Berueffy, Stover was no longer legally state president and should relinquish his office to vice-president Leonard Hoffman, the leader of anti-Stover forces in Iowa. ${ }^{22}$

The argument was clearly a contrived effort to eliminate Stover. The timing of Berueffy's response (less than one week after the Iowa convention ended) strongly suggests that Hoffman or Patton, or both, had concocted the scheme in advance. Patton's decision to consult Berueffy, someone unaffiliated with the Union, could be considered an extraordinary attempt at_impartiality. In consulting one outside authority, however, Patton also avoided the lengthy battle that might have ensued had he either consulted a number of impartial outsiders or referred the question to the NFU's executive committee, board of directors, or entire membership. By relying on the advice of one attorney, Patton got what he wanted-a quick solution to a sticky problem. He also managed to avoid any discussion of inconvenient facts. Stover had, by this time, resigned his position in the Progressive Party. Moreover, Patton had also served as vice-chairman of the National Citizen's Political Action Committee. In 1944, he had successfully defended his right to hold the national presidency when critics charged that he had violated the NFU's rules against partisan activity. Although Patton had opposed this ploy when used against him, he fully supported it when used against Stover. Patton's attempt failed, however. In April, 1951 the Iowa courts declared that Fred Stover was the legitimate president of the Iowa Farmers Union. ${ }^{23}$

22. Report of James G. Patton to the Executive Committee, 31 October 1950, series no. 1, box 4, NFU Papers; Berueffy to Patton, 29 September 1950, series no. 7, box 2, NFU Papers.

23. Chambers, "Relations Between Leaders," 30. See also Fred Stover's closing speech to the September 1951 Iowa Farmers Union annual convention, box 6, U.S. Farmers Association Records, Special Collections Department, University of Iowa Libraries. 
TWICE DEFEATED in his attempts to remove Stover, Jim Patton wrote Wisconsin Farmers Union president Ken Hones that the national board of directors would "have to take specific action in relation to Iowa." He could not isolate Stover from the Iowa Farmers Union, but he could try to isolate the Iowa Farmers Union from the rest of the NFU by revoking its charter. Of course, Patton and the national leadership had no intention of permanently banning Iowa farmers from membership. After cancelling the charter of the Stover-led Iowa Farmers Union, they planned to revive the state group under more cooperative leadership. ${ }^{24}$

Some Iowans favored this approach. Dwight Anderson, who had unsuccessfully challenged Stover for the Iowa Farmers Union presidency in 1948, asked the national organization to "revoke or suspend the charter of the Iowa Farmers Union as soon as possible, and then come in and set up a new organization. ${ }^{25}$ North Dakota president Glenn Talbott, Patton's closest ally in the attempt to unseat Stover, candidly admitted that neither the NFU nor its supporters in Iowa had any "sound, legal grounds for revocation or cancellation of the Iowa Farmers Union Charter." ${ }^{26}$ Still, Patton forces used the organization's historic fiftieth anniversary convention in 1952 as the springboard for the strategy.

Patton and Talbott arrived at the Dallas convention determined to eliminate the annoying elements that the national president now derisively described as the NFU's "tadpoles." ${ }^{27}$ Working closely with other national figures, Patton designed a constitutional amendment that would increase affiliates' minimum membership requirement from 1,000 to 3,500 . Organi-

24. Patton to Hones, 25 May 1951, box 53, Wisconsin Farmers Union Papers, State Historical Society of Wisconsin.

25. Anderson to Patton, 2 July 1951, box 9, Talbott Family Papers, Special Collections, University of North Dakota Library.

26. Talbott to Leo Paulson, 18 October 1951, box 9, Talbott Family Papers.

27. In a letter to Montana's Oscar Horsford, Patton wrote that Harold Ridenour, Fred Stover, and the editors of Facts for Farmers made him "feel like the man who said, 'I would not mind being swallowed by a whale, but I'll be damned if I intend to be irritated to death by tadpoles." Patton to Horsford, 28 March 1952, box 10, folder 5, Talbott Family Papers. 
zations failing to meet the minimum membership by the end of 1953 faced charter revocation. ${ }^{28}$ The amendment jeopardized five affiliates: Oregon (which had a paid membership of 3,407), Michigan $(2,919)$, Texas $(2,634)$, Iowa $(2,296)$, and the Eastern Division $(3,213) .{ }^{29}$ As was evident from both preconvention planning and subsequent actions, however, the change was aimed exclusively at Iowa and the Eastern Division, the two regional affiliates that continued to criticize U.S. foreign policy.

In the weeks leading up to the convention, Patton loyalists laboriously drafted and redrafted the rationale for the constitutional change. At one point, the writers toyed with directly censuring Fred Stover. In the end, however, they decided upon an executive committee "Statement and Recommendation" that refrained from citing specific individuals yet clearly was directed at the two organizational affiliates who most vocally opposed the NFU's recent endorsement of President Truman's foreign policy. ${ }^{30}$

The statement "upheld the right of the individual to his views and of a minority to be heard and to have its views considered." But, it continued, "Liberty is not license and the improper and dangerous actions and methods of a relatively small minority within the organization may no longer be ignored." Specifically, the statement claimed that a "small group" of NFU members had participated in a series of "wrongful and dangerous acts." These wrongdoers had, like dictators, attempted "to control, divide, confuse, [and] conquer." They had distributed publications "financed by unknown sources" that were "deliberately misleading." When NFU officials attempted to contact members and ex-members who disagreed with these unnamed men, they had held "their own state boundaries to

28. "The Proposed Amendments to the Constitution and By-Laws of the National Farmers Union: An Analysis of Their Meaning and Effect," series no. 5, box 4, book 1 (Exhibit File: NFU Convention, 1952 Biennial Convention, Dallas, Texas, March 10-14), NFU Papers.

29. "Delegates Certified to Golden Jubilee 1952 National Convention," series no. 5, box 4, folder 1, Minutes and Proceedings, Convention, 1952, NFU Papers.

30. Handwritten and typed drafts and redrafts and related correspondence can be found in box 9, folder 44, Talbott Family Papers. 
be inviolable." Finally, they had used educational funds "in violation of the rights of ... other states and of National Farmers Union. ${ }^{\prime 31}$ In concise form, the executive committee's statement reviewed the charges that had been levelled against the Iowa Farmers Union since the start of the Korean War. It is unclear, however, whether the executive committee's statement was ever presented to the convention or whether it merely existed as a justification should the need have arisen.

The organizational structure of the Dallas convention precluded the possibility of meaningful discussion of the issues. Convention delegates' votes were weighted, each vote given more or less weight depending on the membership strength of the affiliate they represented. It was possible, therefore, for Glenn Talbott's North Dakota delegation, which represented over one-fourth of the national membership, to dominate decisions with the support of just a few other affiliates. The Talbott-Patton forces knew that they could attain their objective even without debate and so sat mute as the proposed constitutional amendment was introduced.

Simeon Martin, from the threatened Michigan affiliate, was the first of many speakers who opposed the change. He reminded delegates how difficult it was to organize in regions that were "sewed up tight with the reactionary Farm Bureau." Fred Stover reiterated Martin's observation, adding that the constitutional change represented an alarming denunciation of "the very things we stand for." Eastern Division executive secretary Louis Slocum followed, claiming that it was foolish to adopt a proposal that made the organization neither bigger nor more powerful. After further comments from Stover, a Washington state delegate argued that he would be unable to face the membership in his state if the amendment passed. Oklahoma's Roscoe Beale, who felt that the change placed unnecessary hardships on smaller states, pleaded for rejection of the amendment.

Prior to the vote, not one delegate spoke in support of the proposed change. Yet when it came time to vote, the measure

31. "Statement and Recommendation," February 1952, box 9, folder 44, Talbott Family Papers. 
passed overwhelmingly. The threatened affiliates in Oregon, Michigan, Iowa, and the Eastern Division opposed the amendment, as did Minnesota and some dissenting individuals in Kansas, Nebraska, and Oklahoma. Their combined vote, however, was overpowered by individual votes from Kansas, Nebraska, and Oklahoma, and block votes from Arkansas, Montana, North Dakota, South Dakota, Wisconsin, the Rocky Mountain Division, and, surprisingly, the threatened state of Texas. After the balloting, a South Dakota delegate who favored the action naively claimed that no affiliate would actually face charter revocation. Iowa's Merle Hansen, a close friend of Fred Stover, offered a more realistic assessment when he described the convention action as being driven by "the substance of hysteria." Hansen predicted that the delegates had just authored "the articles of suicide" for the National Farmers Union. ${ }^{32}$

THE SILENCE of the Patton-Talbott contingent gave the Dallas convention a conspiratorial air. Their substantial planning had paid off, but they might have been overprepared. ${ }^{33}$ They held enough votes to quash dissent and manned the key positions in the parliamentary regulation of the proceedings. Patton's supporters merely had to show up, cast their votes, and quietly listen to, or perhaps ignore, their opponents' futile objections. Constitutional amendments that tightened the controlling grip of the national leadership were passed in the same fashion as the membership requirement amendment - without one word of support. Elections were managed in a similar fashion. For example, national vice-presidential candidate Marie Holte gave a ten-minute election speech while her opponent, incumbent Herb Rolph, declined to speak. Holte, who had introduced a peace resolution at the November 1951 North Dakota

32. Transcript of convention debate, pp. 164-91, series no. 5, box 4, book 2 (Master Proceedings File), NFU Papers.

33. In addition to the extensive preconvention work on the executive committee's "Statement and Recommendation," the national leadership arrived in Dallas with a "file of letters" from Iowa's pro-Hoffman forces that they suspected would be "extremely helpful" in obtaining converts. Glenn J. Talbott to James G. Patton, 26 February 1952, box 10, folder 3, Talbott Family Papers. 
Farmers Union convention, was resoundingly defeated. Peace resolutions also got the silent treatment. When Simeon Martin called for the renunciation of colonialism and the withdrawal of U.S. armed forces "from foreign soil," committee members listened "in silence," gave his resolution scant consideration, and then declined to present it to the convention for discussion. ${ }^{34}$

Despite the Dallas Morning News's banner headline announcing "Farmers Union Defeats Issue on Cease-Fire," there was no "bitter floor fight" over the Korean War. Actually, the carefully orchestrated convention muzzled Fred Stover's supporters and their efforts to debate foreign policy. A Rank and File Committee circulated a "Statement of Principles" that objected to "some Farmers Union leaders' endorsement of the gigantic . . . war mobilization program. . .." Those leaders, the committee argued, had "capitulated to the fantastic and fatal delusion that farm prosperity can be attained through a gigantic warspending program" and had accepted "the fiction that the present foreign policy is the road to peace and prosperity." Dismissing Soviet imperialism from the program committee's list of "major threats to true world brotherhood and peace," the Rank and File Committee asked the convention to recognize only one significant danger: "the existence in the world of uncorrected and indefensible evils that provided the seed bed for agitation, uprising, and revolt." In calling for U.S. withdrawal from Korea, the committee noted that events in that nation had been produced by "starvation, exploitation, feudalism, [and] dictatorships," not the determination of the Soviet Union "to exploit every wrong for her own imperialistic purposes," as the NFU's proposed policy statement suggested. Finally, the committee called for an American agenda that rejected the "threat of political and economic penetration" as an instrument of foreign policy. These strongly worded denunciations of U.S. policy, which at previous NFU conventions had echoed through every address, now were heard only in hallways and hotel rooms. Besides Marie Holte's references to "farm boys . . . in some far off place shooting people

34. Transcript of convention debate, pp. 70-71, 164-91, series no. 5, box 4, book 2 (Master Proceedings File), NFU Papers; Iowa Union Farmer, November 1951, April 1952. 
and being shot for something they know not what," the only speech that even remotely suggested criticism of American policy was made by Scotland's Lord Boyd Orr, the former head of the U.N.'s Food and Agriculture Organization. ${ }^{35}$

Facts for Farmers reported a more accurate version of events when it declared that the top officers of the National Farmers Union had struck "a heavy pro-Truman note" at Dallas. ${ }^{36}$ Jim Patton, reversing his earlier criticisms of American unilateralism, argued that events in Korea had left the United States "no choice but to maintain a protective shield of military strength to protect free nations against possible military aggression by would-be totalitarian world rulers." Secretary of Agriculture Charles Brannan, invited by Patton to address the convention, spoke in similar terms. The United States, Brannan said, was "willing to spend billions on defense-because we clearly must." Brannan concluded, "[W]e cannot afford to allow a billion people to fall under the domination of the Kremlin if aid from us will prevent it." All that was needed to make the proTruman celebration complete was President Truman himself, but Truman declined Patton's invitation. When he sent his regrets, however, Truman praised the National Farmers Union and expressed his belief that the organization would "continue to support a strong, forward-looking foreign policy." ${ }^{137}$

35. Dallas Morning News, 15 and 11 March 1952; Farmers Union National Rank and File Committee, "Statement of Principles" and "To All Delegates and Members," series no. 5, box 4, folder 1, Minutes and Proceedings, Convention 1952, NFU Papers; "Program Committee Policy Statement," series no. 5, box 4, book 1 (Exhibit File: NFU Convention, 1952 Biennial Convention, Dallas, Texas, March 10-14), NFU Papers. Lord Boyd Orr merely observed that there was "a mass uprising against imperialism of the white man in the Far East." Transcript of convention debate, pp. 70-71, series no. 5, box 4, book 2 (Master Proceedings File), NFU Papers.

36. Facts for Farmers was a monthly publication of Farm Research, Inc., a New York-based organization. See Lowell Dyson, "Radical Farm Organizations and Periodicals in America, 1920-1960," Agricultural History 45 (1971), 111-20.

37. Facts for Farmers, April 1952; Dallas Morning News, 13 March 1952; "Report of James G. Patton, President, National Farmers Union, 1952 Convention, Dallas, Texas, March 10, 1952," and Truman to Patton, 8 March 1952, box 17, folder titled National Farmers Union, Dallas Conference 3/52, Herbert J. Waters Papers, Harry S. Truman Library, Independence, Missouri. 
In 1952, nobody could predict how long the National Farmers Union would pursue its new-found support for Truman's policies. What was obvious, however, was that the organization had altered its political orientation. The NFU had done more than accept a more aggressive American role in world affairs. At Dallas, it had also compromised a number of other views that had defined the organization. It now encouraged private enterprise and opposed "governmental agricultural collectives." It cautiously avoided condemning Farm Bureau proposals to move poorer farmers off the land; it also avoided recommending an accelerated price support program for agriculture. As the Rank and File Committee observed, these positions were a complete violation of the traditions of the NFU. "Never before," the committee charged, "has the National Farmers Union identified itself with exploiting business interests, placed limitations on the cooperative movement, [or] advocated a program of scarcity. ${ }^{\prime 38}$ Not only had it relinquished its role as foreign policy critic, but it also had abandoned the premise that American unilateralism damaged the domestic welfare of the nation's farmers. Discarding their old articles of faith, the leaders of the NFU adopted new policy positions that supported American strength abroad, minimized direct government assistance to farmers, and, reflecting the insecure temper of the times, allowed no room for organizational dissent.

After the convention, Jim Patton remarked that opponents of the organization's new direction had put on a "very shady and shabby performance. ${ }^{139}$ The truth was, however, that the national president and his backers were the ones guilty of underhanded tactics, particularly in the orchestration of constitutional restructuring to purge Fred Stover and other "heretics" from the NFU. As the new 3,500-person minimum membership requirement took effect in 1953, it became obvious that the restructuring had been instituted for no other reason than to remove Cold War critics from the organization.

38. "Program Committee Policy Statement," series no. 5, box 4, book 1 (Exhibit File: NFU Convention, 1952 Biennial Convention, Dallas, Texas, March 10-14), NFU Papers; Farmers Union National Rank and File Committee, "To All Delegates and Members," series no. 5, box 4, folder 1, NFU Papers.

39. Patton to Aubrey Williams, 20 April 1952, box 7, folder 16, Patton Papers. 
THE NATIONAL FARMERS UNION'S internal divisions hurt membership drives in each of the five states potentially targeted by the new charter revocation clause. Perhaps because the quarrel had taken place in its own backyard, the Texas affiliate was the most severely damaged. By 1953, its membership had dropped 59 percent, from 2,634 to 1,069. Iowa's membership dropped by 43 percent, from 2,296 to 1,311. A part of this decline in lowa may have been due to the controversial position of the Iowa Farmers Union, but Iowa membership also fell because anti-Stover forces urged members to boycott the affiliate. Michigan lost 32 percent of its membership, the Eastern Division lost 28 percent, and Oregon lost 20 percent of its members. ${ }^{40}$ Despite the decline in enrollment, each of the five affiliates still met the one-thousand-member minimum originally prescribed by the National Farmers Union constitution. The Dallas revision, however, had made each a potential victim.

When the national board of directors met in Denver on March 13, 1954, it considered an executive committee report that detailed the membership situations of the five affiliates and recommended appropriate action. This was a remarkable document, not only because of its obvious bias against Iowa and the Eastern Division, but also because of the rationalizations it contained. These justifications reveal much about the true motivations of the National Farmers Union.

Texas, the state that had lost the greatest percentage of members between 1952 and 1953, now had the lowest membership total of any of the organization's fifteen affiliates. The executive committee reminded the board of directors, however, that Texas was "the original home of the Farmers Union" and its affiliate was directed by officers who were "capable, conscientious and hard working." In addition, the Texas affiliate's insurance program was "soundly developing and expanding." For these rea-

40. Membership decreased as follows: Michigan (2,919 to 1,980); Eastern Division $(3,213$ to 2,329$)$; and Oregon $(3,407$ to 2,711$)$. For a recapitulation and analysis of membership declines among threatened affiliates, see "A Report of the Executive Committee of the Board of Directors of Farmers Educational and Cooperative Union of America to the Full Board Regarding the Future Status of Those State Organizations of the Farmers Union Which Had Failed to Reach a Membership of 3500 by the End of the 1953 Fiscal Year," series no. 14, box 2, folder 1, NFU Papers. 
sons, the executive committee recommended leaving Texas's charter status "undisturbed."."11

The executive committee also recommended sustaining Oregon's charter, in part because of its thriving insurance program. While the official state membership was 2,711, Oregon could claim more than three thousand National Farmers Union automobile insurance policyholders. The newly elected state president had promised to develop this potential membership pool, and so the executive committee believed that the "activities and energies" of the Oregon affiliate could be "properly marshalled and guided." 42

Finally, the executive committee recommended that the Michigan Farmers Union be allowed to retain its charter, although its reasons for making this recommendation were unclear. The committee report vaguely referred to "existing obstacles" that had been surmounted, the recent improvement in the "public attitude toward [the] Farmers Union," and "several organizational changes" that had "already borne considerable fruit." The report concluded that there were "few, if any [negative factors] with respect to our future in this state. ${ }^{143}$

The executive committee was not so optimistic about the Eastern Division. Dredging up a new rationale for charter revocation, the report described "a material dissimilarity" in the populations of Pennsylvania and New Jersey, the two states constituting the Eastern Division. The executive committee argued that it might have been a mistake to have ever combined the two into one unit. Since "conscientious officers have failed to achieve a coordinated effort" between the two states, and since farmers in Pennsylvania had declined "for reasons of their own ... to join or participate as long as the present charter situation prevails," the executive committee report suggested revoking the charter of the Eastern Division and then pursuing an "independent charter status" for Pennsylvania. The report warned that "further study and discussion" would be necessary before opening an aggressive membership cam-

41. Ibid., 1-2.

42. Ibid., 2.

43. Ibid., 2. 
paign in New Jersey. ${ }^{44}$ The committee's recommendation deliberately avoided any mention of foreign policy disputes between the state and national leaderships. It also failed to mention that Alvin Christman and Louis Slocum, the two vocal critics of U.S. foreign policy who headed the Eastern Division, managed the affiliate from their offices in New Jersey.

The executive committee recommended revoking Iowa's charter as well. It praised the strength of the affiliate in the early history of the NFU, but noted that farmers in Iowa, "for whatever reasons they may have ... will not join [the] Farmers Union in that state as it is presently constituted." The "continuing deterioration in the effectiveness" of the state organization stood in stark contrast to the "abundant evidence that a new and fresh organizational start in Iowa would receive wide and effective farmer support. ${ }^{\prime 45}$ Again, the recommendation never referred to foreign policy differences, presenting the case for charter revocation instead as a remedy to organizational ineffectiveness.

Not surprisingly, the national board of directors adopted the recommendations of the executive committee and revoked the charters of Iowa and the Eastern Division on March 13. Three days before the final decision was made, Fred Stover was summoned to Chicago to meet with NFU representatives Gus Geisler and Charles Brannan. The purpose of the meeting, Stover later reported, was to give the Iowa leader a last chance to save the state's charter. If he agreed to step down as president and allow the NFU to handpick a new leader "who never had any connections or associations with the Iowa Farmers Union," Geisler and Brannan argued that Stover could save embarrassment for himself personally, for his state membership, and for the NFU as a whole. ${ }^{46}$

Stover declined their offer and instead issued a "fact sheet" summarizing the events leading up to charter revocation. Stover,

44. Ibid., 2-3.

45. Ibid., 3.

46. "Fact Sheet: Statement by the Iowa Farmers Union," Stover Papers. Gus Geisler was an organizer for the National Farmers Union. Charles Brannan had been President Truman's Secretary of Agriculture, but became an NFU adviser thereafter. 
along with Alvin Christman, also published a statement describing the NFU action as "a shortsighted decision" that would "comfort only our enemies." Unlike the national leadership, who remained purposely vague about the decision, Stover, Christman, and Iowa member Lee Harthan developed thorough summaries that questioned the wisdom of reducing the organization's membership at a time when "join[ing] together for mutual protection" seemed to be the more logical goal. Harthan urged Patton to seize the opportunity "to heal all the sores that exist in the Union." ${ }^{17}$

The time for healing, however, had passed, at least in the mind of Jim Patton. As the Korean War ended, the NFU president could take comfort that his purge had at last succeeded. Unfortunately, however, this purge did little to diminish the public's negative impressions of the National Farmers Union. Despite the NFU's support for U.S. policy in Korea, New Hampshire Senator Styles Bridges assailed the organization on the floor of the U.S. Senate. In a two-hour address, Bridges described the Communists' "considerable, if not complete, success" in infiltrating the NFU. The NFU was also the subject of antiCommunist attacks orchestrated by the Utah division of the American Farm Bureau. In a pamphlet titled How You Can Fight Communism, a Texas American Legion post charged Communist subversion within the NFU. In 1951 the House Un-American Activities Committee initiated investigations of the NFU during hearings on "communist activities among farm groups." The public's unchanged perception is reflected in the astonished statement of a Pennsylvania woman who learned that the courts had ruled in favor of the National Farmers Union in a 1953 libel case. "What was wrong with the courts?" she wanted to know. "Was it not well established that the Farmers Union was Communist-infiltrated?"48

47. "Fact Sheet," Stover Papers; "Statement of Iowa Farmers Union and Eastern Division of the National Farmers Union," 16 March 1954, Stover Papers; Harthan to Patton, 10 March 1954, series no. 14, box 2, folder 1, NFU Papers.

48. Congressional Record, 81st Cong., 2d sess., 7 September 1950, 14276-14296; United States Court of Appeals, Tenth Circuit, Utah State Farm Bureau Federation et al vs National Farmers Union' Service Corporation et al, 11 June 1952, box 17, Waters Papers; National Union Farmer, May 1951; U.S. Congress, House, 
BETWEEN THE END OF THE KOREAN WAR and his death in 1985, Jim Patton rarely spoke about the purge. When he did, he insisted that the NFU's actions against Stover and the Iowa Farmers Union had nothing to do with differences of opinion over Korea in particular or over American foreign policy in general. Instead, Patton claimed, the fight against Stover and the Iowa Farmers Union had been necessary because of the Iowa leader's inability to build membership in his state. He characterized Stover not as a subversive, nor as a Communist, but as a "total non-conformist" who was "so cantankerous" and "so goddamn crazy" that he had to be removed for the sake of organizational unity. ${ }^{49}$

Although National Farmers Union officials still defend this argument, the facts tell another story. Fred Stover was not removed from the National Farmers Union for membership deficiencies, nor for organizational ineffectiveness. He and the other members of the Iowa Farmers Union were purged because they challenged President Truman's foreign policy. Rumors that their challenge was Communist-inspired represented a threat to the continued existence and effectiveness of the National Farmers Union, an organization that Jim Patton sought to preserve at all cost. In the dark days of the early Cold War, maintaining principles opposed to mainstream thought was a dangerous proposition. Fred Stover and the Iowa Farmers Union stood firm against containment and, in so doing, paid the price of dissent in an era of national hysteria.

Committee on Un-American Activities, Hearings Regarding Communist Activities Among Farm Groups: Hearings Before the Committee on Un-American Activities 82d Cong., 1st sess. (1951); Information from the Files of the Committee on Un-American Activities, 1 April 1957, pp. 1-2, series no. 14, box 2, NFU Papers; Irene B. Stanford to Ezra Benson, 15 April 1953, box 2320, folder titled Publications 4-2, RG 16, National Archives.

49. Charles Livermore, Transcript of Columbia oral history interview with Jim Patton, August 1978, pp. 93-96, box 1, Patton Papers. 
Copyright of Annals of Iowa is the property of State of Iowa, by \& through the State Historical Society of Iowa and its content may not be copied or emailed to multiple sites or posted to a listserv without the copyright holder's express written permission. However, users may print, download, or email articles for individual use. 